\title{
TroyAcademy
}

International Journal of Social Sciences

\section{Bir Grup Tarikat Sancağında Sanat ve Sembolizm}

\author{
Araştırma Makalesi/Research Article
}

\section{Ali Osman UYSAL ${ }^{*}$ Elif CEYLAN EROL ${ }^{* *}$}

\section{ÖZET}

Tarih boyunca devletlerin, orduların, siyasi ya da dinî mahiyetteki akım ve grupların alâmetleri olarak karşımıza çıkan sancaklar, bazen bayrak ile örtüşen anlam ve işlevler de üstlenmişlerdir. Daha ziyade âskerî alanda ordu ve devlet simgesi niteliğiyle tanınan sancağın İslam sûfiliğinde tarikatlar tarafından da kullanıldığı dikkati çekmektedir. Tarikatlarda kullanılan sancaklar biçimsel açıdan diğer sancaklarla benzer olmakla birlikte ait oldukları tarikatlara dair semboller ve ibareler taşımaları bakımından farklılık göstermektedirler. Türk ve İslam toplumlarında farklı dönemlere ait sancakların biçimleri ve anlamlarına yönelik araştırma ve yayınlarda tarikat sancaklarına da değinilmiştir. Fakat bu çalışmalarda tarikat sancaklarının ikonografik ve Türk sanatındaki yeri konuları yeterince incelenmemiştir. Bu yönüyle ilgi çeken tarikat sancaklarından; Ankara Etnografya Müzesi, Akşehir Nasreddin Hoca Arkeoloji ve Etnografya Müzesi ile Yozgat Müzesi'nde yer alan 17 adet örnek ayrıntılı biçimde incelenerek değerlendirilmişlerdir. Makalede sancağın tarikatlarda kullanımı hakkında bilgi verildikten sonra; adı geçen müzelerdeki sancaklar malzeme, teknik, süsleme açılarından tanımlanmışlar ve sembolik boyutlarıyla değerlendirilmişlerdir. 19. yüzyılın ikinci yarısı ile 20. yüzyılın başlarına tarihlendirdiğimiz sancakların bir kısmında yazılar, bazılarında yazılarla birlikte geometrik motifler ve nesnelerle yapılan süslemeler vardır. Bir grup sancak ise yazısız olup nesnelerle yapılan süsleme mevcuttur. Sembolik açıdan ise; bir tarikat sancağı, sûfinin nefsine karşı verdiği mücadeleyi yansitır.

\section{Anahtar Kelimeler: Tarikat, Sancak, Süsleme, Sembolizm}

\section{Art and Symbolism in a Group of Sect Banner}

\begin{abstract}
Throughout history, the banners are the signs of states, armies, political or religious movements and groups have sometimes assumed with meanings and functions that correspond to the flag. Rather, it is noteworthy that the banner, which is known as a symbol of the army and the state in the military field, is also utilized by religious sects in Islamic sufism. Although the banners used in the sects were similar to the other banners in terms of form, but they diverse in that they carry symbols and phrases for the sects they belong to. In the researches and publications on the forms and meanings of the banners belonging to different periods in Turkish and Islamic societies, sect banners also have been mentioned. However, in these studies, the iconographic and the place of sect banners in Turkish art were not sufficiently examined. Among the sect banners that attracted attention with these aspects, 17 samples were examined and evaluated in detail from Ankara Ethnography Museum, Akşehir Nasreddin Hodja Archeology and Ethnography Museum and Yozgat Museum. In the article, after giving information about the use of the banner in sects: the banners in the aforementioned museums have been defined

\footnotetext{
* Prof. Dr., Çanakkale Onsekizmart Üniversitesi Fen-Edebiyat Fakültesi Sanat Tarihi Bölümü. e-posta: aouysal@comu.edu.tr, ORCID ID: https://orcid.org/0000-0002-2427-1791

*** Arş. Gör., Sanat Tarihi. e-posta: mgeecey@gmail.com, ORCID ID: https://orcid.org/0000-0002-6578-9925
} 
in terms of material, technique, and ornaments and evaluated in terms of their symbolic dimensions. Some of the banners, which we dated from the second half of the 19th century to the beginning of the 20th century have inscriptions, some of them have geometric motifs with inscriptions and ornamnets made with objects. In symbolic terms; a sect banner externalize the struggle of the Sufi against his soul.

Keywords: Sect, Banner, Ornament, Symbolism

\section{GíRiş}

Sancak kelime olarak Türkçe "batırıp saplamak" anlamındaki "sancmak" fiilinden türemiştir" ve "Bayrak", "Alay bayrağı" olarak da tanımlanmaktadı³. Sancaklar büyük boyutlu ve gönderli olmaları bakımından bayraklardan ayrılırlar". Bayrak ve sancaklar genellikle savaşlarda "devletlerin alametleri" olarak kullanılmıştır ${ }^{5}$. Eski dönemlerde bu amaçla madeni alemler kullanılırken Orta Çağ'la birlikte kumaştan üretilmiş bayraklar kullanılmıştır6

Tarih boyunca farklı toplumlar tarafindan kullanılan sancaklara Türk-İslam devletlerinde de rastlanmaktadır. Türklerde İslamiyet öncesinde de bayrak, tuğ kullanımı vardır. Bahaeddin Ögel Türklerde kullanılan bayrakların at kılları ya da bez ile sırıktan oluşan bir maddenin ötesinde anlamları olduğunu ifade etmiş, Türklerde bayrak kullanımının ve bayrağa yüklenen anlamların eski din ve devlet inanışlarından kaynaklandığını belirtmiştir ${ }^{7}$. İslamiyet' in kabulünden sonra da Türkler arasında sancak kullanımı devam etmiş ve hakimiyet sembollerinden birisi olarak değerini korumuştur. Karahanlılar' da bayrak kırmızı renk olup savaşlarda orduda bayraklar da yer almaktadır ve bağımsızlık sembolüdür ${ }^{8}$. Büyük Selçuklu Devleti bünyesindeki farklı devletlerin hükümdarlarının kendilerine ait özel renklerde bayraklarının olması da buna örnektir'

İslam toplumlarında sancaklara Hz. Peygamber'in kullandığı sancaklarla ilişkilendirilerek manevi bir anlam yüklenmiştir. Hz. Peygamber'in sancağı "Livâ-i Saadet, Livâ-i Şerif, Livâü'l Hamd” gibi isimlerle anılmaktadır ${ }^{10}$. Hz. Peygamber'in bu sancağı "mahşer gününde" taşıyacağı ve müminlerin bu sancak altında toplanacakları ifade edilmiştir. İslam devletlerinde de Hz. Peygamber'in taşıdığı sancaklara istinaden farklı renklerde sancaklar kullanılmıştır ${ }^{11}$. Hz. Peygamber'in beyaz ve siyah

\footnotetext{
${ }^{1}$ Celal Esad Arseven, “Sancak”, Sanat Ansiklopedisi, C. 4, İstanbul 1975, s. 1760.

${ }^{2}$ Hasan Bey Hadi (Der.), “Sancaq”, Divan-ü Lugat-it Türk’den Derlenmiş Etimolojik Sözlük, Tebriz 2005, s. 639.

${ }^{3}$ Ferit Devellioğlu, "Sancâk” Osmanlıca-Türkçe Ansiklopedik Lûgat, Ankara 2004, s. 919.

${ }^{4}$ Celal Esad Arseven, a.g.mad., s. 1760.

${ }^{5}$ M. Zeki Pakalın, "Sancak”, Osmanlı Tarih Deyimleri ve Terimleri Sözlüğü III, İstanbul 1993, s. 116.

${ }^{6}$ Orhan F. Köprülü, "Bayrak”, TDV İslam Ansiklopedisi, C. 5, İstanbul 1992, s. 247.

${ }^{7}$ Bahaeddin Ögel, Türk Kültür Tarihine Giriş, C. 6, Ankara 2000, s. 1,9.

${ }^{8}$ Reşat Genç, Karahanlı Devlet Teşkilatı, Ankara 2002, s. 94.

${ }^{9}$ Mehmet Altay Köymen, Selçuklu Devri Türk Tarihi, Ankara 1993, s. 12.

${ }^{10}$ Safer Baba, Tasavvuf Terimleri Istılâhât-ı Sofiye fî Vatan-ı Asliye, (Ed. Derya Çakır Baş), İstanbul 1998, s. 241.

${ }^{11}$ Annamarie Schımmel, Tanrı'nın Yeryüzündeki İşaretleri, (Çev. Ekrem Demirli), İstanbul 2004, s. 58.

Bu konuda Hz. Peygamber' in şöyle söylediği rivayet edilmektedir: 'Kıyamet gününde insanlar dirildiği zaman ilk dirilecek olan benim. Topluluklar halinde geldikleri zaman ben onlar adına konuşacağım. Ümitsizliğe düştükleri zaman ben onlara müjde vericiyim. Livau'l-Hamd benim elimdedir. Ben Rabbimin nezdinde ademoğlunun en şereflisiyim. Bunu iftihar için
} 
renkte birçok sancağı olduğu ifade edilmektedir. Siyah olan "Ukâb” olarak adlandırılmaktadır ve Hz. Ayşe'nin kapı perdesinden yapıldığı rivayet edilmektedir. Dört halife devrinde bu sancak seferlere götürülmüştür. Daha sonraki devirlerde Osmanlı'ya geçmiştir'12.

Türk-İslam toplumlarında sancakların askeri alan dışında özellikle de sembolik kullanımıyla ön plana çıktığı saha tarikatlardır. Tarikatlarda sancak, kaynağı Hz. Peygamber'in sancak kullanmasına dayanan, her tarikatın kendine özgü özelliklerini içeren tarikat eşyaları $\operatorname{arasındadır}^{13}$. Buna Orta Çağ'dan itibaren her tarikatın kendilerine ait farklı renklerdeki sancaklarla "şehirlerde geçit alaylarına" katılmaları örnektir ${ }^{14}$.

Tarikatlarda sancaklar genellikle tekkelerde mihrabın iki yanına, tarikat mensuplarına ait türbelerde sandukaların arkasına asılı olarak kullanılmıştır. Bunun yanı sıra sembolik anlamlarıyla tarikatlara ait yazı-resimlerde de kullanılmıştır ${ }^{15}$.

Sancak kullanımının en fazla dikkat çektiği tarikatlar arasında Rifâiyye gelmektedir. Bu tarikatta sancak tarikatın piri olan Ahmed er-Rifâîn'nin “atribüsü” olmuştur ve kendisi “ebu'l-alemeyn” olarak adlandırılmaktadır ${ }^{16}$. Kadiriyye tarikatının tekkelerinde sancak ya "tevhidhanede" mihrabın iki yanına ya da türbede sandukanın arka kısmına asılmıştır ${ }^{17}$. Sa'diyye tarikatında sancağın kullanıldığı özel bir tören vardır. Tarikatta biat sırasında şeyh ve dervişin başına sancak örtülerek "temsili mahfil" oluşturulmakta ve bu mahfilin altında şeyh müride "biatın esrarını" anlatmaktadır. Bektaşilikte halifeye verilen emanetler arasında sancak da yer almakta ve bu sancak üzerinde tarikata ait "esaslar" yazılmaktadir ${ }^{18}$.

Tarikatlarda sancak en belirgin anlamıyla "nefsin terbiyesi için cihada her an hazır olunması" anlamını ifade etmektedir ${ }^{19}$. Rifâîyye tarikatında sancak sembolizmi "bunlar işleri güçleri nefissle savaşmaktan ibaret olan dervişlerin fakr/Hakk’a muhtaçlık ordusunda duruş ve sebatlarına işaret eder. İslam

söylemiyorum" başka bir hadiste bu "kerem sancağı” olarak geçmektedir”. Kadı İyaz, Şifa-i Şerif, (Terc. Suat Cebeci), Ankara 2012, s. 135.

12 M. Tayyib Gökbilgin, "Sancak-1 Şerîf”, MEB İslâm Ansiklopedisi, C. 10, İstanbul 1979, s. 189.; Mustafa Sabri Küçükaşçı, “Mukaddes Emanetler' in Anlamı ve İstanbul'u Şereflendirmesine Dâir”, Keşkül Dergisi, S. 31, İstanbul 2014, s. 27.

${ }^{13}$ Güldane Gündüzöz, “Tekke Hayatında Üç Muktedir Figür: Sancak, Alem ve Tuğ”, Türk Kültürü ve Hacı Bektaş Veli Araştırma Dergisi, S. 85, 2018, s. 164.

${ }^{14}$ Annamarie Schımmel, a.g.e., s. 58. Bu konuda minyatür örnekleri için bkz. Nurhan Atasoy, Derviş Çeyizi: Türkiye'de Tarikat Giyim-Kușam Tarihi, İstanbul 2016, s. 38, 45.

${ }^{15}$ Hümeyra Uludağ, "Tekke Yazılarında Sancak Sembolizmi”, Keşkül Dergisi, S. 9, İstanbul 2006, s. 107-108.

${ }^{16}$ Hümeyra Uludağ, 2006, a.g.m, s. 108. Rifâîyyede Ahmed er-Rifâi’ye “ebu'l-alemeyn” adı verilmesinin sebebi olarak kendisine "Abdülkadir Geylani’den sonra gavsiyetin verilmesi ve bu yolla kutupluk ve gavslık makamlarının birleşmiş olması, zahir ve batın ilimlerde asırlarının tek büyüğü olarak görülmesi” gösterilmektedir. Ken'an er-Rifâi, Seyyid Ahmed Er-Rifâî, (Haz. Mustafa Tahralı), İstanbul 2015, s. 225i.

${ }^{17}$ Hümeyra Uludağ, "Kâdiriyye Tarîkatında Sembolik Ögeler”, Keşkül Dergisi, S. 18, İstanbul 2011, s. 79.

${ }^{18}$ Hümeyra Uludağ, 2006, a.g.m, s. 108.

${ }^{19}$ Enver Behnan Şapolyo, Mezhepler ve Tarikatlar Tarihi, İstanbul 1964, s. 165. 
askerleri düşman karşısında nasıl sebat edip, onlara haddini bildirmeye kalkışırsa, dervişlerin de böylece insanın en büyük düşmanı olan nefs-i emmârenin terbiyesi için topluca gayrette bulunduklarına bir delil demektir" şeklinde ifade edilmektedir ${ }^{20}$. Bu anlamla ilişkili olarak da tarikat sancaklarına Kelime-i Tevhid, Fetih Suresi başta olmak üzere fetih ve zaferle ilgili ayetler, aktâb-1 erbaanın ve tarikat pirinin ismi, Zülfikâr, hilal, pençe-i âl-i aba gibi semboller işlenmiştir. Bunun yanı sıra bir tarikata mensup olan herkesin mahşerde pirinin sancağı altında toplanacağına ve o sancak altında Livâ'ül Hamd'a ulaşılacağına inanılmıştır²1. Sancağın mihrabın yanına asılması ise "fethin kaynağı olan Allah'ın salike kapıları birer birer açarak maksada ulaştıracağına remiz” olmasına işaret etmektedir ${ }^{22}$.

Türk-İslam toplumlarında farklı dönemlerde kullanılan sancakların şekilleri ve anlamları hakkında kitap, makale, tez gibi muhtelif çalışmalarda bilgiler sunulmuştur ${ }^{23}$. Sancaklar Türk-İslam sanatına ait önemli dokuma örnekleri olarak tez çalışmalarında da yer almıştır ${ }^{24}$. Tarikat sancaklarıyla ilgili özellikle sembolik anlamlarını ifade eden makale türünde yayınlar ${ }^{25}$ mevcut olmakla birlikte bu sancakların Türk sanatındaki yeri ve sanat tarihi disiplini çerçevesinde incelenmesine dair çalışmaların eksikliği görülmektedir. Bu çalışmamızda Ankara Etnografya Müzesi, Akşehir Nasreddin Hoca Arkeoloji ve Etnografya Müzesi ve Yozgat Müzesi'nde ${ }^{26}$ yer alan 17 adet sancak malzeme-teknik, süsleme açısından incelenerek tanıtılmıştır. Eserlerden 13 adedi Ankara Etnografya Müzesi'nde, 2 adedi Akşehir Nasreddin Hoca Arkeoloji ve Etnografya Müzesi'nde ve yine 2 adedi Yozgat Müzesi’nde bulunmaktadır.

${ }^{20}$ Ken'an Rifâi, a.g.e., s. 223.i.

${ }^{21}$ Anonim, "Sancak", Keşkül Dergisi, S. 31, İstanbul 2014, s. 44.

Rivayete göre Bedeviyye tarikatının piri Ahmed el-Bedevi bir gün rüyasında kıyametin koptuğunu ve mahşerde olduğunu görmüştür. Hz. Peygamber kendisine "Sana kutlu olsun ey Ahmed” diye buyurmuş, "Ne ile kutluyorsun beni ey Allah'ın Resulü” diye sorunca "Seni başının üzerinde yükselen bu sancakla kutluyorum” cevabını almıştır. Ahmed el-Bedevi başını kaldırınca üzerinde nurla “Ahmed el-Bedevî ve müridlerinden ve sadık dervişlerinden O'nunla birlikte olanlar için Allah'ın yardımı ve fethi yakındır” yazılı büyük bir sancak görmüştür. Derya Baş, Seyyid Ahmed el-Bedevî Tarîkatı ve İstanbul'da Bedevîlik, İstanbul 2008, s. 158.

${ }^{22}$ Hümeyra Uludağ, 2011 , a.g.m, s. 79.

${ }^{23} \mathrm{Bu}$ konudaki çalıșmalara Bahaeddin Ögel, Türk Kültür Tarihine Giriș, C. 6, Ankara 2000.; Mahmut Enes Soysal, "Tarihsel Süreçte Bayrak ve Sancaklarımız", A.Ü. Türkiyat Araştırmaları Enstitüsü Dergisi, S. 42, Erzurum 2010, ss. 209-239.; Elif Şahintürk, "16. Yüzyıl Osmanlı Minyatürlerinde Bayrak Üzerine Bir Araştırma (Bayrak-Flâma-Sancak)”, Marmara Üniversitesi Türkiyat Araştırmaları Enstitüsü Türk Sanatı Anabilim Dalı Yüksek Lisans Tezi, İstanbul 2011. eserleri örnektir.

24 Sancakların çalışıldığı tezlere Aliye Çoban, “Tokat Müzesi'nde Bulunan İşlemeli Sancak Örnekleri”, Selçuk Üniversitesi Sosyal Bilimler Enstitüsü Eı Sanatları Eğitimi Anabilim Dalı El ve Makine Nakışları Eğitimi Bilim Dalı Yüksek Lisans Tezi, Konya 2013. örnektir.

${ }^{25}$ Sancağın tarikatlardaki sembolik anlamlarına yönelik çalışmalara Hümeyra Uludağ, 2006, a.g.m., s. 107-109.; Güldane Gündüzöz, a.g.m., s.161-181. örnektir.

${ }^{26}$ Çalışma talebimize olumlu cevap veren ve çalışma sırasında yardımlarını esirgemeyen adı geçen müze müdürlüklerine ve personeline teşekkür ederiz. 
Çalışmamızda incelenen on yedi adet sancak biçimsel olarak benzer olduklarından dolayı "yazılı" ve “yazısız” olmalarına göre kataloglanarak tanıtılmıştır. Eserlerden Kat. No. 1.-Kat. No. 14 (Resim 114) olan eserler yazılı; Kat. No. 15-Kat. No. 17 (Resim 15-17) olanlar ise yazısız sancaklardır.

\section{ANKARA ETNOGRAFYA MÜZESI, AKŞEHİR NASREDDİN HOCA ARKEOLOJİ VE ETNOGRAFYA MÜZESİ İLE YOZGAT MÜZESİ'NDE YER ALAN SANCAKLAR}

\subsection{Tarihlendirme ve Aidiyet}

Sancaklardan bazılarında açık olarak tarih ibaresi yer alırken bazılarında ait oldukları tarikatın pirinin ismi ya da tarikata ait semboller işlenmiştir. Kat. No. 5 olan eserde H. 1294/M. 1877-1878 tarihinin yanı sıra Halvetiyye'nin Şabaniyye koluna ait olduğunu ifade eden ibare ve Halvetiyye tâc-1 şerifinin üstten görünüşü olan gül mühür (Resim 5), Kat. No. 6 olan sancağın üzerinde H. 1293/M. 1876-1877 tarihi ve sancağın Bedeviyye tarikatına ait olduğunu ifade eden ibareler ve bir de Bedeviyye tarikatında kullanılan gül mühür (Resim 6), Kat. No. 7 olan sancakta H. 1320/M. 1902-1903 tarihi (Resim 7), Kat. No. 9 olan eserde H. 1328/M. 1910-1911 tarihi (Resim 9), Kat. No. 13 olan sancakta H. 1313/M. 18951896 tarihi ve sancağın Rifâîyye tarikatına ait olduğunu ifade eden Ahmed er-Rifâî adı vardır. (Resim 13) Kat. No. 1 olan sancakta Dussukîyye tarikatının piri olan İbrahim Dussukî’nin (Resim 1), Kat. No. 3 olan sancakta Rifâîyye tarikatının piri olan Ahmed er-Rifâî’nin (Resim 3), Kat. No. 8 olan sancakta ve Kat. No. 14 olan sancakta Kadiriyye tarikatının piri olan Abdülkâdir Geylanî’nin adı ve tarikata ait gül mühür işlemesi yer almaktadır. (Resim 8,14$)$ Diğer sancaklarda tarikat ya da tarih işaret eden bir ibare yoktur.

İncelenen sancaklar arasında tarihini bildiğimiz en erken örnek Kat. No. 6 olup 1876-1877 tarihlidir. En geç tarihli örnek ise Kat. No. 9 olup H. 1328/M. 1910-1911 tarihlidir. Toplamda beş adet sancakta tarih ibaresi, yedi adet örnekte ise ait oldukları tarikata ait ibareler ve semboller varken diğerlerinde mevcut değildir. Eserlerden biri Bedeviyye (Kat. No. 6), birisi Halvetiyye-Şabaniyye (Kat. No. 5), birisi Dussukiyye (Kat. No. 1), ikisi Rifâiyye (Kat. No. 3, 13) ve ikisi de Kadiriyye (Kat. No. 8, 14) tarikatlarına aittir. $\mathrm{Bu}$ örnekler ve benzer sancaklar (Resim 18,19) dikkate alınarak değerlendirildiğinde 19. yüzyıl sonlarında sancaklarda yazılarla birlikte bir takım nesneli süslemenin de olduğu, 20. yüzyıl başlarında ise nesneli süslemenin daha da yaygınlaştığı görülmektedir. Bundan hareketle tarihi olmayan eserlerden yazının ağırlıkta olduğu örnekleri 19.yüzyıl sonu, nesnenin ağırlıkta olup yazının hemen hemen ortadan kalktığı örnekleri ise 20. yüzyıl başı ve sonrasına tarihlendirmek mümkündür. 


\subsection{Malzeme ve Teknik}

İncelenen sancaklarda ortak malzeme kumaş, yapım tekniği ise dokumadır. Süsleme tekniği olarak aplike, baskı ve işleme görülmektedir. Sancakların kenar temizlemeleri ya farklı renk kumaş dikilerek ya da sancağın kenarının kıvrılması ile yapılmış, kenar temizlemelerinde bazı örneklerde süsleme görülürken bazıları boş bırakılmıştır.

Kat. No. 1, Kat. No. 2, Kat. No. 4, Kat. No. 8, Kat. No. 10, Kat. No. 13, Kat. No. 14, Kat. No. 15, Kat. No. 17 olan eserin kenar temizlemesi farklı bir kumaşın dikilmesiyle oluşturulurken, Kat. No. 5, Kat. No. 6, Kat. No. 7, Kat. No. 9, Kat. No. 11, Kat. No. 12 olan eserlerin kenar temizlemesi kenarların iplikle kıvrılmasıyla yapılmıştır. Kat. No. 3, Kat. No. 16 olan eserlerin kenar temizlemesi ise püsküldür. Kat. No. 3, Kat. No. 4, Kat. No. 14 olan eserlerde kenar temizlemelerinde yazı varken Kat. No. 10 olan eserde geometrik süsleme mevcuttur.

Süsleme tekniklerinde Kat. No. 4, Kat. No. 7, Kat. No. 9, Kat. No. 11, Kat. No.15, Kat. No. 16, Kat. No. 17 olan sancaklarda motifler; Kat. No.1, Kat. No. 5 olan sancaklarda yazılar; Kat. No. 6, Kat. No. 10, Kat. No. 12 olan sancaklarda yazılar ve motifler; Kat. No. 13 olan sancakta madalyonlar aplike tekniği ile uygulanmıştır. Kat. No.2, Kat. No. 7, Kat. No. 9 olan sancaklarda yazılar; Kat. No.5, Kat. No. 6 olan sancaklarda küçük yazılar ve gül mühürler; Kat. No. 8 olan sancakta gül mühür işleme tekniği ile yapılmıştır. Kat. No.3, Kat. No.8, Kat. No. 13 ve Kat. No. 14 olan eserlerde yazılar baskı tekniği ile uygulanmıştır. Kat. No. 4 olan eserde ise yazıların olduğu kumaşlar, harflerin içleri kesilerek, esas zeminine dilmiş böylece zeminde tezat renkte yazılar elde edilmiştir.

\subsection{Süsleme}

Araştırma kapsamında incelenen sancaklarda süsleme kompozisyonlarını yazı, geometrik motifler ve nesneler oluşturmaktadır. Kat. No.1, Kat. No. 2, Kat. No. 13 olan eserlerde süsleme sadece yazı kompozisyonundan oluşmaktadır. Kat. No. 15, Kat. No. 16 ve Kat. No. 17 olan eserlerde yazı kompozisyonu yoktur, süsleme geometrik motifler ve nesnelerle oluşturulmuştur. Diğer sancaklarda ise yazı, geometrik motifler ve nesneli bezeme bir arada yer almaktadır. Bunun dışında herhangi bir adlandırma yapılamayacak kadar stilize motifler de süslemede yer almıştır.

Yazı kompozisyonlarının içeriğini ayetler, tarikat pirlerinin adları, Kelime-i Tevhid, Esma'ül Hüsna, Besmele, aşere-i mübeşşere isimleri, on iki imam adları, dört halifenin isimleri, ehl-i beyt adları, bazı dua ve zikirler ile bazı sancaklarda da tarihler oluşturmaktadır. Ayetlerden Fatiha Suresi, Bakara Suresi 255. Ayet, Şûra Suresi 23. Ayet, Nasr Suresi 1. Ayet, Al-i İmran Suresi 126. Ayet, Saff Suresi 13. Ayet, Fetih Suresi 1. Ayet, Mearic Suresi 5. Ayet, Ahzab Suresi 33. Ayet, Yusuf Suresi 64. Ayet, tarikat pirlerinden Abdülkâdir Geylanî, Ahmed er-Rifâî, Ahmed el-Bedevî, İbrahim Dussukî, 
Sa'deddin Cibavî, Şeyh Şaban-1 Veli’nin adları, Esma-ül Hüsnalardan “Allah, Hu, Yâ Âfî, Yâ Kâfî, Yâ Şâfî, Yâ Mûafî", dua ve zikirler arasında "Subhânallâhi velhamdulillâh ve lâ ilâhe illallâhu vallâhu ekber ve lâ havle ve lâ kuvvete illâ billahil aliyyil azim”, "Lâ ilahe illallahu Melikul Hakkul Mübin”, "Yâ Müfettiha'l-ebvâb iftah lena hayra'l-bâb” görülmektedir. Bu sancaklardan Kat. No.4'te Zülfikâr üzerinde "lâ fetâ illâ Ali lâ seyfe illâ Zülfikâr" ve Kat. No. 10'da ise "aslan" ibareleri incelenen diğer sancaklardan farklıdır. Bu ayet, zikir ve dualar farklı tarikat sancaklarında bir arada ortak olarak yer almaktadır. Bunun yanı sıra tarikatlara ait olmayan sancaklarda da anlam ortaklığından dolayı bu ibarelerden bazılarının ortak olarak kullanıldığı görülmektedir²7. Aslan kelime olarak "korkusuzluk, mertlik, güç” gibi anlamları temsil etmektedir. Bunun yanı sıra “Allah'ın aslanı” Hz. Ali için kullanılan bir tabirdir ${ }^{28}$.

Sancaklarda yer alan bu yazıların Hz. Peygamber dönemindeki sancaklarda da mevcut olduğu kaynaklarda geçmektedir. Mekke'nin fethi sırasında Mirdas oğlu Abbas ve Hz. Ali'nin sancaklarında Saff Suresi 13. Ayetin ve yine aynı fetihte taşınan sancaklardan birinin üzerinde Fetih Suresi 1. Ayetin olduğu, ${ }^{29}$ Huzeyl Kabilesine yapılan sefer sırasında Hz. Peygamber'in Hz. Ali’ye üzerinde Kelime-i Tevhid, Avvam oğlu Zubeyr'e Saff Suresi 13. Ayet, Esved oğlu Mikdad'a Al-i İmran Suresi 18. Ayet, Mirdas oğlu Abbas'a "Eşhedü en lâ ilâhe illallâhu vahdehû lâ şerîke leh ve eşhedü enne Muhammeden abduhû ve resûluh”, Ubade oğlu Sad'a İsra Suresi 81. Ayet, Amr oğlu Ka'kaa'ya ise Fetih Suresi yazılı sancak verdiği rivayet edilmektedir ${ }^{30}$.

Yazı istiflerinde yazı-resim grubunda olan örnekler de süsleme açısından önemlidir. Kat. No. 3, Kat. No. 8 ve Kat. No. 14 olan eserlerde "Ali” istiflerinin "ye/ی" harfleri Zülfikâr şeklinde sonlanmaktadır. Kat. No. 8 ve Kat. No. 14 olan eserlerde ortada tarikat pirinin adının yazıldığı istifler ise tâc-1 şerif şeklindedir.

Geometrik motifleri hilal, beş-sekiz-on iki ya da on altı kollu yıldızlar, madalyonlar, daireler oluşturmaktadır. Bu motifler bazı sancaklarda uygulanırken bazılarında uygulanmamıştır. Kat. No. 10 olan eserde bordürde çengel motifi yer almaktadır. Kat. No. 5 olan eserde yazılar arasında Halvetiyye tâc-1 şerifinin üstten görünüşü olan gül mühür işlenmiştir. Kat. No. 6 olan eserde Mühr-i Süleyman içerisinde Bedeviyye tarikatında kullanılan gül mühür yer almaktadır. Kat. No. 8 ve Kat. No. 14 olan eserlerde ise on sekiz tığlı Kadiriyye gülü işlenmiştir.

\footnotetext{
${ }^{27}$ Bu konuda örnekler hakkında ayrıntılı bilgi için bkz. Naci Bakırcı, "Mevlâna Müzesindeki Sancaklar”, Mevlâna Ocă̆ı/ Mevlâna'nın Doğumunun 800. Yılına Armağan, (Mehmet Bayyiğit Ed.) Konya 2007, s. 241-257.; Aliye Çoban, “Tokat Müzesi’nde Bulunan İşlemeli Sancak Örnekleri”, Selçuk Üniversitesi Sosyal Bilimler Enstitüsü Eı Sanatları Eğitimi Anabilim Dalı El ve Makine Nakışları Eğitimi Bilim Dalı Yüksek Lisans Tezi, Konya 2013.

${ }^{28}$ Abdülbâki Gölpınarlı, “Arslan”, Tasavvuftan Dilimize Geçen Deyimler ve Atasözleri, İstanbul 1977, s. 26-27.

${ }^{29}$ Erzurumlu Mustafa Darir Efendi, Büyük İslam Tarihi, (Çev. M. Faruk Gürtunca), C. 6, İstanbul t.y, s. 571-574.

${ }^{30}$ Erzurumlu Mustafa Darir Efendi, a.g.e., C. 5, s.116-120.
} 
Tarikatlarda gül mühürler Kadiriyye ve Nakşibendiyye'de tâc-1 şeriflerin kubbe merkezlerine, Rifâiyye, Sa'diyye, Bedeviyye'de ise arakıyyelerin tepesine işlenmektedir. Bu gül mühürlerin kaynağ1 Hz. Peygamber'e dayandırılmaktadır ve birçok sembolik anlam yüklenmektedir ${ }^{31}$. Kat. No. 6 olan sancaktaki Bedeviyye gül mührü üç daireden oluşmaktadır. Ortada altı kollu yıldızla on iki dilim, diğer iki halkada ise okunamayan ibareler vardır. Bu tarikatta kullanılan gül mühürde Rifâiyye ve Sa'diyye tarikatlarında olduğu gibi Celcelûtiyye Vefki olduğu için okunamayan kısımlarda bu vefkin yazılı olduğu düşünülmektedir ${ }^{32}$. Kat. No. 8 ve Kat. No. 14 olan sancaklardaki gül mühürler on sekiz tığh İsmaili güldür ${ }^{33}$. Kat. No. 5 olan sancaktaki Halvetiyye gül mührünün içinde kufi hatla kelime-i tevhid yazılı olduğu ifade edilmektedir ${ }^{34}$.

Mühr-i Süleyman şekil olarak "birinin tepesi diğerinin tabanına geçmiş iki eşkenar üçgenden”" oluşmaktadır 35 . Hz. Süleyman “Allah tarafından verilen insanüstü kuvvet ve ilme” sahiptir. İç içe ters olarak geçmiş iki üçgenden oluşan Mühr-i Süleyman da bu kuvvetin sembolü ve kaynağı olarak görülerek tarikatlara ait farklı eserler üzerinde uygulanmıştır ${ }^{36}$.

Nesnelerden oluşan süslemede el/pençe-i âl-i abâ, hançer/Zülfikâr, muhafazasında asılı vaziyette Kur'an-1 Kerim sıklıkla uygulanmıştır. Kat. No. 9 olan eserde teber, Kat. No. 10 olan eserde ibrik, Kat. No. 11 olan eserde ise cami motifleri görülmektedir.

El motifi tasavvuf kültüründe "pençe-i âl-i abâ/hamse-i âl-i abâ" kavramları ile ifade edilmektedir. Pençe-i âl-i abâ, Hz. Peygamber, kızı Hz. Fatıma, damadı Hz. Ali ve torunları Hz. Hasan ile Hz. Hüseyin'i temsil etmektedir ${ }^{37}$. Toplam beş kişi oldukları için el şeklinde tasvir edilmişlerdir ${ }^{38}$. Bu kavram bütün tarikatlarda önemli olmuştur ve âl-i abâ sevenleri kendilerine "bende-i âl-i abâ" demişlerdir ${ }^{39}$. Anadolu'da halk kültüründe de el önemli bir simgedir ve duvarlara, bayraklara yapılan el işaretlerinin ya da el şeklindeki muskaların koruyucu bir tılsım olarak algılandığı da görülmektedir ${ }^{40}$. Zülfikâr, Hz. Peygamber'in Hz. Ali'ye verdiği iki tarafı keskin bir kılıçtır. Değişik rivayetler olmakla birlikte bu kılıcın Uhud'da Hz. Ali’ye hediye edildiği bu sırada da "Lâ fetâ illâ Alî lâ seyfe illâ Zülfikâr

\footnotetext{
31 Yahyâ Âgâh b. Sâlih el-İstanbulî, Tarikat Kiyafetlerinde Sembolizm, (Ed. Yusuf Özbek), İstanbul 2002 , s. 203. Sembolik anlamlar için bkz. Yahyâ Âgâh b. Sâlih el-İstanbulî, a.g.e., s. 203-215.

${ }^{32}$ Yahyâ Âgâh b. Sâlih el-İstanbulî, a.g.e., s. 208.

${ }^{33}$ Sembolik anlamları için bkz. Yahyâ Ầgâh b. Sâlih el-İstanbulî, a.g.e., s. 199.

${ }^{34}$ Ayrıntılı bilgi için bkz. Yahyâ Âgâh b. Sâlih el-İstanbulî, a.g.e., s. 212.

35 İskender Pala, "Mühr-i Süleyman”, TDV İslâm Ansiklopedisi, C. 31, İstanbul 2006, s. 524.

${ }^{36}$ Sadi Bayram, “Mühr-ü Süleyman ve Türk Kültürü’ndeki Yeri”, Sanat Tarihinde İkonografik Araştırmalar Güner Inal'a Armağan, Ankara 1993, s. 63.

${ }^{37}$ Cahid Baltac1, Tasavvuf Lügatı, İstanbul 2011, s. 26.; Safer Baba, a.g.e., s. 14.

${ }^{38}$ Ekrem Işın, Selahattin Özpalabıyıklar, “Hoş Gör Yâ Hû” Osmanlı Kültüründe Mistik Semboller Nesneler, İstanbul 1999, s. 65.

${ }^{39}$ Süleyman Uludağ, Tasavvuf Terimleri Sözlüğ̈̈, İstanbul 2016, s. 36.

${ }^{40}$ Malik Aksel, Anadolu Halk Resimleri, İstanbul 2010, s. 74.
} 
nidası duyulduğu" kabul edilmektedir. Zülfikâr İslam coğrafyasında edebiyattan resme birçok alanda sevilerek kullanılan bir motif olmuştur ${ }^{41}$. Osmanlı ordusunda da bu motif yaygın olarak kullanılmıştır. Özellikle 35-36-100 cemaat ortalarının ve 40. bölüğe ait bölük ortalarının çeşitli formlarda Zülfikâr işaretleri mevcuttur ${ }^{42}$.

Teber, bir sapa geçirilmiş tek ya da çift yüzlü baltaya verilen isimdir ${ }^{43}$. Tarikatlarda teber kullanımı Hassân b. Sâbit'in sünneti olarak görülmektedir. Hassân b. Sâbit, Habeş Meliki Necaşi'nin kölesiyken, Hz. Peygamber'e hediye edilmiş, Hz. Peygamber'de kendisine bir nize hediye ederek bunu taşımasını öğütlemiştir. Rivayete göre Hz. Ali'de bu öğüde uyarak teber taşımıştır ${ }^{44}$. Tarikat mensuplarının teber kullanmaları Hz. İbrahim'in putları kırmasıyla da ilişkilendirilmektedir ${ }^{45}$.

İbrik, İslam toplumlarında kişisel temizlikte ve namaz başta olmak üzere ibadetlerin ön şartı olan abdest almayla ilişkili bir nesnedir ${ }^{46}$. Tasavvuf ekollerinin ortaya çıktığı ilk dönemlerde yolculuk sırasında sufilerin yanlarında taşıdıkları eşyalardan birisidir ${ }^{47}$. Bektaşiyye tarikatında “İkrar Ayini”nde talibe rehber olan kişi leğen ve ibrik ile su dökerek abdest aldırmaktadır. Bu abdestten önce ise "leğen ibrik tercümanını" okumaktadır. ${ }^{48}$ Bunun yanı sıra diğer tarikatlarda da ibadetle bağlantılı olarak ibrikler kullanılmıştır. Ayrıca bu motif İslam sanatında birçok malzemede, farklı eserler üzerinde “nazarlık, bereket, su, temizlik, ruhsal ve bedensel arınma, doğum-ölüm, Tanrı'nın nûru, cennet, evren, ibadet" gibi çeşitli sembolik anlamlarla kullanılmıştır ${ }^{49}$.

Ku'an-1 Kerim, son semavi kitap olup Hz. Peygamber'e gönderilmiştir. Bunun yanı sıra “cem ve icmal makamı, insan" gibi anlamları da temsil etmektedir. Hz. Peygamber ve insan-1 kâmil "alemdeki dağınık olarak mevcut olan şeyleri” topladığı için Kur'an olarak adlandırılmaktadır ${ }^{50}$. Sancaklarda Kur'an-1 Kerim'in muhafazası ile asılı vaziyette işlenmesinin belirli ayetlerin yerine tüm ayetleri toplayan Kur'an'ın gösterilmesi olarak yorumlanması da mümkündür.

Cami kelime olarak "cem olunan, toplanılan yer, içinde namaz kılınan ibadet yeri” olarak bilinmektedir. ${ }^{51}$ Cami İslam dininin sembolü olan bir bina olması nedeniyle sembolik açıdan da

\footnotetext{
${ }^{41}$ Mustafa Öz, “Zülfikar”, TDV İslam Ansiklopedisi, C. 44, İstanbul 2013, s. 553-554.

${ }^{42}$ T. Nejat Eralp, Tarih Boyunca Türk Toplumunda Silâh Kavramı ve Osmanlı İmparatorluğunda Kullanılan Silâhlar, Ankara 1993, s. 66.

${ }^{43}$ Abdülbâki Gölpınarlı, "Teber", a.g.e., s. 328.

${ }^{44}$ Yahyâ Âgâh b. Sâlih el-İstanbulî, a.g.e., s. 223.; Anonim, “Teber”, Keşkül Dergisi, S. 31, İstanbul 2014 , s. 71.

${ }^{45}$ Sırrî Kalender, Keşkül-i Sırrî, İstanbul 2012, s. 148.

46 Semiha Altıer, “Osmanlı Sanatı'nda İbrik Tasvirleri ve İkonografisis”, Çanakkale Araştırmaları Türk Yıllığı, S. 26, 2019, s. 153.

${ }^{47}$ Ethem Cebecioğlu, “İbrîk”, Tasavvuf Terimleri ve Deyimleri Sözlüğü, İstanbul 2014, s. 230.

${ }^{48}$ Bedri Noyan, Bektaşîlik Alevilik Nedir?, İstanbul 1995, s. 274.

${ }^{49}$ Semiha Altier, a.g.m., s. 172.

50 Süleyman Uludağ, “Kur’ân”, a.g.e., s. 220-221.

${ }^{51}$ Ferit Devellioğlu, "Câmi'”, a.g.e., s. 124.
} 
önemlidir. Bir hadiste geçen “İslâm’ın binası tek olan Allah’a iman ile dört rükûn yani namaz, oruç, zekât ve haccı kapsamaktadır"52 ifadesi bu hususta önemlidir. İslam'ın emirlerinden en önemlilerinden olan namazın kılındığı cami ile “İslam binası” arasında bu bakımdan bağlantı kurmak mümkündür. Bu motifin sancak üzerinde bulunması ise sancakların askeri kullanım amaçları dikkate alındığında İslam dini ve cihad kavramı arasındaki bağlantıyı düşündürürken tarikatlardaki kullanımı dikkate alındığında camilerin dini ibadetlerin yapıldığı ve bu yolla Allah'ın zikredildiği yerler olmasından dolayı dervişin seyr-i sülûku ile dini kaidelere bağlılığı arasındaki ilişkiyi düşündürmektedir. Bektaşilik ikonografisinde "her insan cami, her insan yüzü de mihraptır; mihrab da o insanın mürşidinin yüzüdür" şeklinde bir sembolik ifade vardır ${ }^{53}$.

\section{KATALOG}

\subsection{Yazılı Sancaklar:}

Kat. No. 1.-Akşehir Nasreddin Hoca Arkeoloji ve Etnografya Müzesi Env. No. 585 Olan Sancak: 170x180cm ölçülerindedir. Sarı renkli sancağın dört yanında kırmızı kenar temizlemesi vardır. Sancaktaki üç satırlık yazıdan orta satır siyah üst ve alt satırlar ise kırmızı renkli kumaştan aplike olarak uygulanmıştır. Sancakta "Bismillâhirrahmânirrahîm Lâ İlâhe İllallah Muhammedün Resûlullah Seyyid İbrahim Dussukî” yazılıdır. (Resim 1)

Kat. No. 2.-Ankara Etnografya Müzesi Env. No. 4382 Olan Sancak: 217x131cm ölçülerindedir. Kırmızı renkli sancağın üç yanında açık yeşil, göndere takılan yanında ise kamuflaj yeşili renkte kenar temizlemesi vardır. Sancağın üzerinde uçları dilimli kemer biçiminde sonlanan dört adet kartuş içerisine beyaz renkli ipliklerle yazılar işlenmiştir. Birinci kartuşun sağ köşesinde "Talhâ radıyallahu anh”, sol köşesinde "Zeyd radıyallahu anh"; son kartuşun sağ köşesinde "Abdurrahman radıyallahu anh", "Sa'd radiyallahu anh", sol köşesinde "Ubeyd radiyallahu anh", "Saîd radiyallahu anh"; kartuşların içerisinde Bakara Suresi 255. Ayet olan "Bismillâhirrahmânirrahîm Allâhü lâ ilâhe illâ hüvel hayyul kayyûm lâ te'huzühû sinetüv velâ nevm lehû mâ fis semâvâti ve mâ fil ard men zellezî yeşfeû ındehû illâ bi iznih ya'lemü mâ beyne eydîhim ve mâ halfehüm ve lâ yühıytûne bi şey'im min ilmihî illâ bi mâ şa' vesia kürsiyyühüs semâvâti vel ard ve lâ yeûdühû hıfzuhümâ ve hüvel aliyyül azıym” yazılıdır. (Resim 2)

Kat. No. 3.-Ankara Etnografya Müzesi Env. No. 7837 Olan Sancak: 141x190cm ölçülerindedir. Siyah renkli sancağın dört yanında yeşil renkli kenar temizlemesi mevcuttur. Sancaktaki yazılar siyah ve

\footnotetext{
52 Sadık Kılıç, İslâm'da Sembolik Dil, İstanbul 2016, s.208.

${ }^{53}$ Frederick de Jong, "Bektaşîlik’te İkonografi”, Tarihten Teolojiye: İslam İnançlarında Hz. Ali, (Haz. Ahmet Yaşar Ocak), Ankara 2014, s. 273.
} 
beyaz renkli olup baskı tekniği ile uygulanmıştır. Kenarlarda yer alan yazılardan soldaki tahrip olduğu için okunamamıştır. Sağ kenardan başlayan alt ve sol kenarın baş kısmını da içeren yazılarda Fatiha Suresi’nin ayetleri olan “Bismillâhirrahmânirrahîm El hamdü lillâhi rabbil âlemîn er rahmânir rahıym mâliki yevmid dîn iyyâke na'büdu ve iyyâke nesteıyn ihdinas sırâtal müstekıym sırâtallezîne en'amte aleyhim ğayril mağdûbi ve aleyhim veled dâllîn.”; üst kenarda Şûra Suresi 23. Ayetin bir bölümü olan "kul lâ es’elüküm aleyhi ecran illel meveddete fil kurbâ", "Lâ İlâhe İllallah Muhammedün Resûlullah" ve bunun üzerinde "Hu Allah" yazılıdır. Sancağın ortasında büyük bir istifle "Ya Ali” yazılmıştır ve “ye/ی" harfi uzatılarak kabzası iki yana çıkıntı yapan çift ağızlı Zülfikâr şeklinde sonlanmıştır. Bu istifin altında "Yâ Hazret-i Pir Şeyh es-Seyyid Sultan Ahmed er-Rifâî", üstünde "Hu Allah Muhammed Fatıma" să̆ yanında "Hasan", sol yanında "Hüseyin" yazılmıştır. Zeminin dört köşesinden sağ üstte "Ebubekir”, sol üstte “Ömer”, sağ altta "Osman”, sol altta ise "Ali” yazılıdır. Sağda yer alan kartuşlardan birinde "Bismillâhirrahmânirrahîm” diğer kartuşlarda ise üstten alta doğru sırayla “Cafer-i Sadık, Zeynel Abidin, Ali Rıza, Ali Naki, Muhammed Mehdi”, sol kartuşlarda üstten alta doğru sırayla "Muhammed Bakır, Musa Kazım, Muhammed Taki, Hasan Askeri,....” İsimleri yer almaktadır. Bu kartuşlar ile kenar arasında ise Nasr Suresi 1. Ayet olan "İzâ câe nasrullâhi vel'feth" yazılıdır. (Resim 3)

Kat. No. 4.-Ankara Etnografya Müzesi Env. No. 3052 Olan Sancak: 170x170cm ölçülerindedir. Beyaz renkli sancağın dört yanında kırmızı renkli kenar temizleme mevcuttur. Kenarlıklarda yer alan yazı kuşakları harflerin sınırlarının kesilerek esas zemin renginin ortaya çıkarılmasıyla oluşturulmuştur. Sancakta farklı renk ve boyutlardaki motiflerin aplike olarak uygulanmasıyla süsleme yapılmıştır. Kenarlıklar ile zemin arasında bir sıra açık mavi renkli dairesel bezeme mevcuttur. Zeminin ortasında ise nazar boncuğunu andırır şekilde iç içe mavi-kırmızı-beyaz, kırmızı-mavi-beyaz, kırmızı-beyaz daireler yer almaktadır. Sancağın tam ortasında kabzası iki yana çıkıntı yapan, iki uçlu büyük bir Zülfikâr motifi ve bunun altında el/pençe-i âl-i abâ yer almaktadır. Elin yanında duran motif ise merkezde beyaz dairenin etrafında kırmızı renkli on dört köşeli ve bunun etrafında mavi renkli on yedi köşeli geometrik bir motiftir. Sancağın sağ üst köşesinde "Ebubekir”, sol üst köşesinde “Ömer”, sağ alt köşesinde "Ali", sol alt köşesinde "Osman"; Zülfikârın bir ağzında "lâ fetâ illâ Ali" diğer ucunda "lâ seyfe illâ Zülfikâr", elin içinde ise "Allah” yazılıdır. Kenarlıklarda sağ yanda "Lâ İlâhe İllallah Muhammedün Resûlullah", sol yanda Al-i İmran Suresi 126. Ayetin bir kısım olan "ve men nasru illâ min indillâhil azîzil hakîm", üstte Saff Suresi 13 Ayet olan "Nasrum minallâhi ve fethûn karîb ve beşşiril mü’minîn” ve "ya Muhammed”, alt kenarda Fetih Suresi 1. Ayet "Bismillâhirrahmânirrahîm İnnâ fetahnâ leke fetham mübînâ" yazılıdır. (Resim 4) 
Kat. No. 5.-Ankara Etnografya Müzesi Env. No. 4038 Olan Sancak: 185x150 ölçülerindedir. Yeşil renkli sancağın yanları iplikle kıvrılarak kenar temizlemesi yapılmıştır. Sancağın üzerindeki yazılar beyaz renkli kumaşların aplike olarak uygulanmasıyla oluşturulmuştur. Birinci ve ikinci satır arasına ise "gül mühür" işlenmiştir. Sancağın üzerinde "Eûzubillâhimineşşeytânirracîm, Ya Allah Bismillâhirrahmânirrahîm Lâ İlâhe İllallah Muhammedün Resulullah sallallahu teala aleyhi ve sellem, Ebubekir radıyallahu anh Ömer radiyallahu anh Osman radiyallahu anh Ali radiyallahu anh Hasan radıyallahu anh Hüseyin radıyallahu anh, Şah Şabandır pirimiz Rahi Hakka Rehberimuz, Hüda yoluna serimuz tarik-i Halvetidir bu, sene 1294" yazılıdır. (Resim 5)

Kat. No. 6.-Ankara Etnografya Müzesi Env. No. 4054 Olan Sancak: 150x125cm ölçülerindedir. Yeşil sancağın yanları iplikle kıvrılarak kenar temizlemesi yapılmıştır. Yazılar beyaz renkli kumaştan aplike olarak, "gül mühür" motifi ise işleme yöntemiyle uygulanmıştır. Sancağın ortasında merkezinde gül mühür olan bir Mühr-i Süleyman ve bunun etrafını "U”, şeklinde saran yazılar yer almaktadır. Mühr-i Süleyman'ın içinde kenarlarda sırasıyla "Ya Allah”, "Ya Muhammed”, “Ebubekir, “Ömer”, “Osman”, “Ali” yazılmıştır. Zemindeki yazılardan birinci satırda "Yâ Hazret-i Abdulkâdir Geylanî Bismillâh (ince yazı Maşallahu kâne ) Errahman” bu satırın bitiminde "Yâ Hazret-i Pir Ahmed er-Rifâ̂”, ikinci satırda Fetih Suresi 1. Ayet olan "Bismillâhirrahmânirrahîm İnnâ fetahnâ leke fetham mübînâ errahıym”, yıldızın etrafını dolaşan üçüncü satırda Bakara Suresi 255. Ayetin bir bölümü olan “Allâhü lâ ilâhe illâ hüvel hayyul kayyûm lâ te'huzühû sinetüv velâ nevm lehû mâ fis semâvâti ve mâ fil ard men zellezî”, en altta "sene 1293 Zilka'de Ahmed Bedevi Dervişi” bunun sağında ise "Yâ Hazret-i Pir Ahmed Bedevî”, solda "Yâ Hazret-i Pir Sa'deddîn Cibâvî” yazılıdır. Kenarlık ile yıldız arasında yatay olan yazılarda birinci satırda Saff Suresi 13 Ayetin bir kısmı olan "Nasrum minallâhi ve fethûn karîb", ikinci satırda “...”, üçüncü satırda Mearic Suresi 5. Ayet olan "Fasbir sabran cemîlâ" yazılmıştır. (Resim 6)

Kat. No. 7.-Ankara Etnografya Müzesi Env. No. 8983 Olan Sancak: 145x170cm ölçülerindedir. Sancak ortada beyaz yanlarda kırmızı olmak üzere üç şeritten oluşmaktadır. Yanların kıvrılmasıyla kenar temizlemesi yapılmıştır. Üç kenarda yer alan yazılar işleme, motifler ise aplike tekniği ile oluşturulmuştur. Sancağın ortasına hilal ve sekiz kollu stilize yıldız motifi yer almaktadır. Bunun devamında kabzasında altı kollu yıldız olan bir hançer ile el/pençe-i âl-i abâ motifi işlenmiştir. Elin üzerinde de hilal ve dokuz kollu yıldız motifi vardır. Kılıcın üzerinde 1320 tarihi yer almaktadır. Üst kenarda Fetih Suresi 1. Ayet olan "Bismillâhirrahmânirrahîm İnnâ fetahnâ leke fetham mübînâ” ve "maşallahu kâne", bu satırın sağ altında "Yâ Allah celle celâluh", sol altında "Yâ Muhammed sallallahu aleyhi ve sellem" yazılmıştır. Sol yan kenarda Saff Suresi 13. Ayetin bir bölümü olan "Nasrum minallâhi ve fethûn karîb” ve "Hasbünallâhu ve ni’mel vekîl tebarekellezi”, alt kenarda 
"Subhânallâhi velhamdulillâh ve lâ ilâhe illallâhu vallâhu ekber ve lâ havle ve lâ kuvvete illâ billahil aliyyil azim", bu satırın altında ise sağdan sola doğru "Hasan Hüseyin radıyallahu anh, Ali radıyallahu anh, Osman radıyallahu anh, Ömer radıyallahu anh, Ebubekir radıyallahu anh” yazılmıştır. (Resim 7) Kat. No. 8.-Ankara Etnografya Müzesi Env. No. 10088 Olan Sancak: 159x143cm ölçülerindedir. Yeşil sancağın dört yanında kahverengi kenar temizlemesi mevcuttur. Yazılar sarı ve beyaz renkli olup baskı tekniği ile yapılmıştır. Kenar temizlemesi ile zemin arasında sarı şerit mevcut olup dört köşe üçgen şeklinde bölünmüş ve içlerine yazı işlenmiştir. Sağ üst köşede "Yâ Şâfî", sol üst köşede "Yâ Kâf̂", sağ alt köşede "Yâ Âfî", sol alt köșede "Yâ Muâfî" yazılıdır. Bunların altında sağ üste "Yâ Hazret-i Pir Seyyid Ahmed er-Rifâî", sol üstte "Yâ Hazret-i Pir Seyyid Ahmed el-Bedevî", sağ altta "Yâ Hazreti Pir İbrahim Dussûkî”, sol altta "Yâ Hazreti Pir Seyyid Sa'deddin Cibâvî” yazılıdır. Zeminin ortasında müsenna "Ali” yazılarının "ye/ى" harfleri karşılıklı iki adet Zülfikâr şeklinde olup kabzalar iki adet eşkenar dörtgen ile belirtilmiştir. "ayn/ع" harflerinin altında "Fatıma” yazılıdır. "Ali” yazısının üzerindeki tâc-1 şerif şeklindeki istifte "Yâ Bâzü'l-eşheb Hazret-i Şeyh Sultan Abdülkâdir Geylânî", bu istifin en üstünde sarı renkle "Yâ Allah Yâ Muhammed" yazılmıştır. Ortadaki bu yazı komposizyonunun sağ üstünde sarı renkle "Ebubekir", sol üstünde "Ömer”, sağ altında "Osman”, sol altında "Ali” yazılıdır. Zemindeki on bir adet dilimli kartuştan sağdakilerde üstten alta doğru "İmam Hüseyin r.a, İmam Hasan r.a, İmam Zeynel Abidin r.a, İmam Muhammed Bakır r.a”, alttaki kartuşlarda “İmam Cafer Sadık r.a , İmam Musa El Kâzım r.a , Ali Musa İmam Rıza r.a”, soldakilerde alttan üste doğru "İmam Muhammed Taki r.a, İmam Ali Naki r.a, İmam Hasan Askeri r.a, İmam Muhammed Mehdi r.a." yazılıdır. Solda kenar ile kartuşlar arasında Fetih Suresi 1. Ayet olan "İnnâ fetahnâ leke fetham mübînâ" yazılıdır. Burada bir de gül mühür işlenmiştir. Sağda kenar ile kartuşlar arasında Ahzab Suresi 33. Ayetin bir bölümü olan "innemâ yurîdullâhü li yüzhibe ankümür ricse” yazılıdır. (Resim 8)

Kat. No. 9.-Ankara Etnografya Müzesi Env. No. 11218 Olan Sancak: 169x161cm ölçülerindedir. Beyaz zeminli sancağın yanlarının kıvrılmasıyla kenar temizlemesi yapılmıştır. Sancağın üzerindeki motifler kırmızı, mavi, sarı, pembe renkli kumaşlarla aplike tekniği ile oluşturulmuştur. Yazılar siyah renkli iplikle suzeni dikişlerle işlenmiştir. Sancağın yanları içe doğru düzgün olmayan geometrik şekillerle süslenmiştir. Sancağın ortasında büyük bir madalyon olup bunun merkezinde sırasıyla nokta şeklinde kırmızı kumaşın etrafında siyah daire şeklinde bir kumaş, sarı renkli sekiz kollu yıldız ve mavi renkli sekiz kollu en dişta ise on altı kollu bir uygulama vardır. Madalyonun üst ve altında yer alan oval kuşaklarda yazılar mevcuttur. Üsttekinde "lâ havle ve lâ kuvvete illâ billahil aliyyil azim"”, alttakinde "Lâ İlâhe İllallah Muhammedün Resûlullah” yazılmıştır. Madalyonun solunda yer alan küçük bir kuşakta ise "sene 1328” tarihi vardır. Zeminde dağınık halde el/pençe-i âl-i abâ, muhafazası 
ile asılı Kur'an-1 Kerim, hançer, teber, hilal ve stilize yıldız, stilize geometrik motifler yer almaktadır. (Resim 9)

Kat. No. 10.-Ankara Etnografya Müzesi Env. No. 11220 Olan Sancak: 159x146cm ölçülerindedir. Beyaz renkli sancağın üç yanında kırmızı renkli kenar temizlemesi mevcuttur. Sancağın üzerine kırmızı ve mavi renkli kumaşların aplike olarak uygulanması ile motifler ve yazılar oluşturulmuştur. Kenarlık ile zemin arasında kırmızı şeritle oluşturulan bordür üst kenar dışında çengel ve aralarında stilize palmet motifleriyle doldurulmuştur. Zemin üst kısımda iki yandan gelen mavi şeritler ve bunların birleştiği yerdeki kırmızı renkli hilal ile iki üçgen parçaya bölünmüştür. İki üçgene de sekiz kollu yıldız ve yazılar işlenmiştir. Sağ tarafta “Allah”, "Muhammed”, “Aslan”, “Allallah”, sol tarafta “Muhammed s.a.v.”, “İllallah alallah esvelehüm” yazılıdır. Sancağın merkezinde büyük bir sekiz kolu yıldız olup bunun merkezinde daha küçük sekiz kollu bir yıldız ve etrafinda beş adet elibelinde motifi yer almaktadır. Yıldız motifinin etrafında üstte iki adet el/pençe-i âl-i abâ, sağ ve solunda dört adet ibrik, iki yanda kılıç, hilal motifleri vardır. En altta ise "Bismillâhirrahmânirrahîm” yazılmıştır. (Resim 10)

Kat. No. 11.-Ankara Etnografya Müzesi Env. No. 11241 Olan Sancak: 164x157cm ölçülerindedir. Beyaz sancağın yanları kıvrılarak kenar temizlemesi yapılmıştır. Sancağın üzerine yeşil, sarı, kırmızı renkte kumaşların aplike olarak uygulanmasıyla motifler ve yazı oluşturulmuştur. Sancak sağ kenar dışında üç yönde sarı-kırmızı ve yeşil renkli elibelinde motifiyle çevrilmiştir. Merkezde üzerinde on bir adet sarı ve yeşil nokta olan kırmızı dairenin içinde tek kubbeli, çift minareli bir cami motifi yer almaktadır. Bunun sağ yanında kılıç motifi sol yanında hilal ve sekiz kollu yıldız görülmektedir. Bunun altında "Allah" yazısı mevcuttur. Sancağın sağ üst köşesinde asılı vaziyetteki Kur'an-1 Kerim'in yanında "Allah ..." yazılıdır. Sancağın alt kısmında ise hançer ve el/pençe-i âl-i abâ motifleri yer almaktadır. (Resim 11)

Kat. No. 12.-Ankara Etnografya Müzesi Env. No. 11253 Olan Sancak: 142x140cm ölçülerindedir. Beyaz renkli sancağın yanları kıvrılarak kenar temizlemesi yapılmıştır. Sancağın üzerinde kırmızı, mavi ve sarı renkli kumaşlardan motifler ve yazılar aplike tekniği ile uygulanmıştır. Sancak üç yönde kırmızı renkli elibelinde motifi ile çevrilmiştir. Sancağın ortasındaki kırk kollu madalyonun merkezinde hilal etrafında 14 kollu yıldız ve bunu çeviren beş adet elibelinde yer almaktadır. Madalyonun etrafında el/pençe-i âl-i abâ, kılıç, hilal gibi motifler vardır. Alt kenarda ise büyük harflerle "Lâ İlâhe İllallah Muhammedün Resûlullah s.a.v” yazılıdır. (Resim 12)

Kat. No. 13.-Yozgat Müzesi Env. No. 1034 Olan Sancak: 155x125cm ölçülerindedir. Yeşil renkli sancağın yanlarında beyaz renkli kenar temizlemesi vardır. Zeminde üst ve alt kenarlarda dört adet 
yuvarlak, ortada bir büyük yuvarlak ile iki yanındaki oval beyaz madalyonlar aplike tekniği ile yapılmıştır. Bunların içinde siyah renkli baskı tekniğinde yazılar mevcuttur. Üst kenarda yer alan madalyonlardan sağ köşedekinde "Ali radıyallahu anh", sol köşedekinde "Ebubekir radıyallahu anh" ortadakilerde "Allah celle celâluhu”, "Muhammed sallalahu aleyli vessellem” yazılıdır. Alt kenarda yer alan madalyonlarda sağ köşede "Osman radıyallahu anh", sol köşede "Ömer radıyallahu anh" ortadakilerde ise "Hasan radıyallahu anh", "Hüseyin radıyallahu anh" yazılıdır. Zeminin ortasında yer alan büyük madalyonun içindeki istifte "el meded Yâ Ebü’l Alemeyn Pir Ahmed er-Rifâî kuddise sırruh, 1313" ibareleri ve tarih kısmının iki yanında ay-yıldız motifi yer almaktadır. Bu madalyonun sağında yer alan madalyonda Saff Suresi 13. Ayet olan "Nasrum minallâhi ve fethûn karîb ve beşşiril mü’minîn" ve "Yâ Muhammed", soldaki madalyonda ise Fetih Suresi 1. Ayet olan "İnnâ fetahnâ leke fetham mübînâ" yazılmıştır. (Resim 13)

Kat. No. 14.-Yozgat Müzesi Env. No. 1035 Olan Sancak: 170x170cm ölçülerindedir. Yeşil sancağın üç yanında kahverengi kenar temizlemesi mevcuttur ve yazılar beyaz renkli baskı ile işlenmiştir. Kenar temizlemelerindeki yazılardan bir kısmı silinmiştir. Bu kısımda köşelerde daire içinde altı kollu yıldız formunda hat istifi mevcuttur. Bunların arasında kalan madalyonlardan üst kenarda sağdan sola doğru “İmam Hasan Askeri, İmam Muhammed’ül Mehdi, Fatmat'üz Zehra” okunabilmiştir. Bu da diğer madalyonlarda on iki imamın isimlerinin yazılmış olduğunu göstermektedir. Sancağın sağ üst köşesinde “Allah”, sol üst köşesinde "Muhammed”, sol kenarında “Osman”, sağ alt köşede "Ali”, sol alt köşede "Ebubekir" yazılıdır. Yine dört köşede dört adet dilimli kartuş içerisinde de yazılar vardır. Sağ üst kartuşta Saff Suresi 13. Ayetin bir kısmı olan "Nasrum minallâhi ve fethûn karîb" sol üst kartuşta aynı ayetin devamı olan “ve beşşiril mü'minîn” ve "Yâ Muhammed”, sağ alt köşedekinde Fetih Suresi'nin 1. Ayeti olan “İnnâ fetahnâ leke fetham mübînâ”, sol alt köşedekinde "Ya Müfettiha'lebvâb iftah lena hayra'l-bâb” yazılıdır. Sancağın ortasında müsenna "Ali” hattı olup "ye/ى" harfleri kabzaları iki eşkenar dörtgen şeklinde dışa taşıntı yapan Zülfikâr şeklinde sonlanmaktadır. Bu hattın üzerindeki tâc-1 şerif şeklindeki istifte "Yâ Bâzü'l-eşheb Hazret-i Şeyh Sultan Abdülkâdir Geylânî” yazılıdır. Bunun üzerinde "Bismillâhirrahmânirrahîm", sağında "Lâ ilahe illallahu Melikul Hakkul Mübin" ve kırmızı kufi hatla "Ya Allah", sol tarafında "Muhammed resûlullah hakkan ve sıdkan" yazılıdır. En altta ise Yusuf Suresi 64. Ayet olan "fellâhü hayrun hâfizav ve hüve erhamür râhımîn sadakallahülazim” yazılıdır. Sol yanda yazılar ile kenar arasında gül mühür yer almaktadır. (Resim 14)

\subsection{Yazısız Sancaklar}

Kat. No. 15.-Akşehir Nasreddin Hoca Arkeoloji ve Etnografya Müzesi Env. No. 584 Olan Sancak: 152x164cm ölçülerindedir. Zemin kırmızı, yeşil ve beyaz renkli üç şerit halinde olup alt kenarda düz, diğer üç kenarda ise dilimli motifleri olan kenar temizlemesi vardır. Beyaz olan zemin boşken diğer 
şeritlerin üzerinde beyaz renkli kumaştan aplike yöntemiyle süsleme oluşturulmuştur. Sancağın üzerinde üç adet iki hilal arasında on iki ve on altı kollu yıldız, iki adet el/pençe-i âl-i abâ, bir adet hançer ve bir de muhafazasında Kur'an-1 Kerim işlenmiştir. (Resim 15)

Kat. No. 16.-Ankara Etnografya Müzesi Env. No. 8982 Olan Sancak: 135x115cm ölçülerindedir. Beyaz sancağın yanlarında püskül şeklinde kenar temizlemesi vardır. Sancağın üzerinde kırmızı, mavi, sarı, yeşil kumaşların aplike olarak uygulanmasıyla motifler oluşturulmuştur. Zeminin etrafı farklı renkte, iki yanı dilimli kumaşlarla çevrilmiştir. Merkezde hilal ve beş kollu yıldız vardır. Bunun solunda hançer motifi olup sancağın üzerinde el/pençe-i âl-i abâ motifinin yanı sıra tam olarak anlamlandıramadığımız farklı şekiller de mevcuttur. (Resim 16)

Kat. No. 17.-Ankara Etnografya Müzesi Env. No. 11239 Olan Sancak: 143x143cm ölçülerindedir. Beyaz zeminli sancağın yanlarında sade ve motifli, farklı renklerde kumaşlarla kenar temizlemesi vardır. Sancağın üzerine kırmızı, pembe ve mavi başta olmak üzere sade ve desenli kumaşlardan motifler aplike olarak uygulanmıştır. Merkezde otuz bir dilimli karenin içinde siyah şeritle sol üst köşe üçgen şeklinde kesilmiştir. Merkezde kare kırmızı kumaşın üç köşesinde mavi bir köşesinde siyah kumaş, bunun da içinde mavi, kırmızı ve siyah kumaşlar vardır. Sağ kenarda iki uçta karşılıklı hilal ve y1ldız motifleri mevcuttur. Alt kenarda alt alta asılı iki adet muhafazalı Kur'an-1 Kerim yer almaktadır. (Resim 17)

\section{SONUÇ}

Tarih boyunca farklı medeniyetler tarafindan devletlerin ve toplumların ayırt edici simgelerinden birisi olarak kullanılan sancaklar Türk-İslam devletlerinde de önemli bir yere sahip olmuştur. İslam toplumlarında kaynağını ve kutsallığını Hz. Peygamber'in kullandığı sancaklardan alan bu eser türü askeri alanın dışında tarikatlarda da kullanılmıştır.

Tarikatlarda kullanılan sancaklar biçimsel özellikleri açısından diğer sahalarda kullanılan sancaklara benzemekle birlikle ait oldukları tarikatlara dair sembol ve ibarelerle farklılık göstermektedir. Bunun yanı sıra bu sancaklara birçok sembolik anlam da yüklenmektedir. Tarikatlarda kullanılan sancakların en belirgin sembolik özelliği bir devletin düşmana karşı giriştiği mücadelede sancak açması gibi tarikat mensubunun da nefsine karşı giriştiği mücadeleyi temsil etmesidir.

Çalışmamız kapsamında incelediğimiz sancak örneklerinde malzeme kumaş yapım tekniği ise dokumadır. Süslemede aplike, baskı ve işleme teknikleri kullanılmıştır. İncelenen sancaklardan üç adedinde yazı mevcut değildir. Süslemeyi oluşturan kompozisyonlar ise yazı, geometrik motifler ve nesneli bezemeden oluşmaktadır. Yapılan değerlendirmede incelediğimiz tarikat sancaklarındaki yazıların içeriğinin çoğunlukla dini ibarelerden oluştuğu ve farklı sancak örnekleri ile taşıdıkları 
anlamdan dolayı benzer olduğu, nesnelerle yapılan süslemede Zülfikâr, el/pençe-i âl-i abâ gibi sembollerin de diğer sancaklarda kullanıldığı görülmektedir. Bunun yanı sıra tarikat pirlerinin isimlerinin ya da tarikata ait gül mühürlerin işlenmesi bu sancakların tarikatlara aitliğini belirten ve diğer sancak örneklerinden ayıran en önemli unsurlardır.

Çalışmamızda yer alan 19. yüzyılın ikinci yarısına ve 20. yüzyıl başlarına ait olan sancak örnekleri tarikatlardaki kullanımları ile birçok sembolik anlamı ifade etmelerinin yanı sıra sanat tarihi ve kültür tarihi açısından önemli etnografik eserler olarak dikkat çekmektedir. Malzeme-teknik, süsleme bakımından ve sembolik açıdan değerlendirildiğinde tarikat sancakları Türk-İslam dokuma sanatının kıymetli örneklerindendir. 


\section{KAYNAKÇA}

Aksel, Malik, Anadolu Halk Resimleri, İstanbul 2010.

Altıer, Semiha, “Osmanlı Sanatı'nda İbrik Tasvirleri ve İkonografisi”, Çanakkale Araştırmaları Türk Yıllı̆̆g, S. 26, 2019, s. 149-202.

Anonim, “Sancak”, Keşkül Dergisi, S. 31, İstanbul 2014, s. 44.

Anonim, “Teber”, Keşkül Dergisi, S. 31, İstanbul 2014, s. 71.

Arseven, Celal Esad, "Sancak”, Sanat Ansiklopedisi, C. 4, İstanbul 1975, s. 1760-1762

Atasoy, Nurhan, Derviş Çeyizi: Türkiye'de Tarikat Giyim-Kuşam Tarihi, İstanbul 2016.

Bakırcı, Naci, “Mevlâna Müzesindeki Sancaklar”, Mevlâna Ocağı/ Mevlâna’nın Doğumunun 800. Y1lına Armağan, (Ed. Mehmet Bayyiğit) Konya 2007, s. 241257.

Baltac1, Cahid, Tasavvuf Lügatı, İstanbul 2011.

Baş, Derya, Seyyid Ahmed el-Bedevî Tarîkatı ve İstanbul'da Bedevîlik, İstanbul 2008.

Bayram, Sadi, "Mühr-ü Süleyman ve Türk Kültürü'ndeki Yeri”, Sanat Tarihinde İkonografik Araştırmalar Güner İnal'a Armağan, Ankara 1993, s. 61-72.

Cebecioğlu, Ethem, Tasavvuf Terimleri ve Deyimleri Sözlüğü, İstanbul 2014.

Çoban, Aliye, “Tokat Müzesi’nde Bulunan İşlemeli Sancak Örnekleri”, Selçuk Üniversitesi Sosyal Bilimler Enstitüsü El Sanatları Eğitimi Anabilim Dalı El ve Makine Nakışları Eğitimi Bilim Dalı Yüksek Lisans Tezi, Konya 2013.

Devellioğlu, Ferit, "Sancâk” Osmanlıca-Türkçe Ansiklopedik Lûgat, Ankara, 2004, s. 919.

Eralp, T. Nejat, Tarih Boyunca Türk Toplumunda Silâh Kavramı ve Osmanlı İmparatorluğunda Kullanılan Silâhlar, Ankara 1993.

Erzurumlu Mustafa Darir Efendi, Büyük İslam Tarihi, (Çev. M. Faruk Gürtunca), C. 5-6, İstanbul t.y.

Genç, Reşat, Karahanlı Devlet Teşkilatı, Ankara 2002.

Gökbilgin, M. Tayyib, “Sancak-1 Şerîf”, MEB İslâm Ansiklopedisi, C. 10, İstanbul 1979, s. $189-191$.

Gölpınarlı, Abdülbâki, Tasavvuftan Dilimize Geçen Deyimler ve Atasözleri, İstanbul 1977.

Gündüzöz, Güldane, “Tekke Hayatında Üç Muktedir Figür: Sancak, Alem ve Tuğ”, Türk Kültürü ve Hacı Bektaş Veli Araştırma Dergisi, S. 85, 2018, s. 161-181. 
Hasan Bey Hadi (Der.), Divan-ü Lugat-it Türk'den Derlenmiş Etimolojik Sözlük, Tebriz 2005.

Işın, Ekrem, Özpalabıyıklar, Selahattin, "Hoş Gör Yâ Hû” Osmanlı Kültüründe Mistik Semboller Nesneler, İstanbul 1999.

Jong, Frederick, "Bektaşîlik’te İkonografi”, Tarihten Teolojiye: İslam İnançlarında Hz. Ali, (Haz. Ahmet Yaşar Ocak), Ankara 2014, s. 251-276.

Kadı İyaz, Şifa-i Şerif, (Terc. Suat Cebeci), Ankara 2012.

Ken'an er-Rifâî, Seyyid Ahmed Er-Rifâî, (Haz. Mustafa Tahralı), İstanbul 2015.

K1lıç, Sadık, İslâm'da Sembolik Dil, İstanbul 2016.

Köprülü, Orhan F. “Bayrak”, TDV İslam Ansiklopedisi, C. 5, İstanbul 1992, s. 247-254.

Köymen, Mehmet Altay, Selçuklu Devri Türk Tarihi, Ankara 1993.

Küçükaşçı, Mustafa Sabri, "Mukaddes Emanetler'in Anlamı ve İstanbul'u Şereflendirmesine Dâir”, Keşkül Dergisi, S. 31, İstanbul 2014, s. 21-28.

Noyan, Bedri, Bektaşîlik Alevilik Nedir, İstanbul 1995.

Ögel, Bahaeddin, Türk Kültür Tarihine Giriş, C. 6, Ankara 2000

Öz, Mustafa, “Zülfikar”, TDV İslâm Ansiklopedisi, C. 44, İstanbul 2013, s. 553-554.

Pakalın, M. Zeki, "Sancak”, Osmanlı Tarih Deyimleri ve Terimleri Sözlüğü III, İstanbul 1993, s. 116-119.

Pala, İskender, "Mühr-i Süleyman”, TDV İslâm Ansiklopedisi, C. 31, İstanbul 2006, s. 524-526.

Safer Baba, Tasavvuf Terimleri Istılâhât-1 Sofiye fî̀ Vatan-1 Asliye, (Ed. Derya Çakır Baş), İstanbul 1998.

Schımmel, Annamarie, Tanrı'nın Yeryüzündeki İşaretleri, (Çev. Ekrem Demirli), İstanbul 2004.

Sırrî Kalender, Keşkül-i Sırrî, İstanbul 2012.

Soysal, Mahmut Enes, "Tarihsel Süreçte Bayrak ve Sancaklarımız", A.Ü. Türkiyat Araştırmaları Enstitüsü Dergisi, S. 42, Erzurum 2010, s. 209-239.

Şahintürk, Elif, “16. Yüzyıl Osmanlı Minyatürlerinde Bayrak Üzerine Bir Araştırma (Bayrak-Flâma-Sancak)”, Marmara Üniversitesi Türkiyat Araştırmaları Enstitüsü Türk Sanatı Anabilim Dalı Yüksek Lisans Tezi, İstanbul 2011.

Şapolyo, Enver Behnan, Mezhepler ve Tarikatlar Tarihi, İstanbul 1964. 
Uludağ, Hümeyra, “Tekke Yazılarında Sancak Sembolizmi”, Keşkül Dergisi, S. 9, İstanbul 2006, s. 107-109.

Uludağ, Hümeyra, Kâdiriyye Tarîkatında Sembolik Ögeler, Keşkül Dergisi, S.18, İstanbul 2011, 74-80.

Uludağ, Süleyman, Tasavvuf Terimleri Sözlüğü, İstanbul 2016.

Yahyâ Âgâh b. Sâlih el-İstanbulî, Tarikat Kıyafetlerinde Sembolizm, (Ed. Yusuf Özbek), İstanbul 2002. 


\section{RESIMLER}

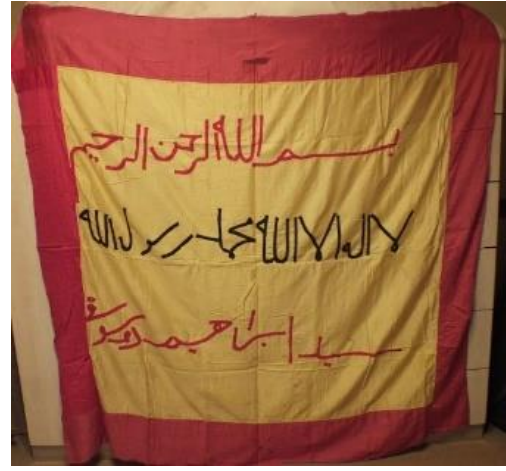

Resim 1: Kat. No. 1 (Ceylan Erol, 2018)

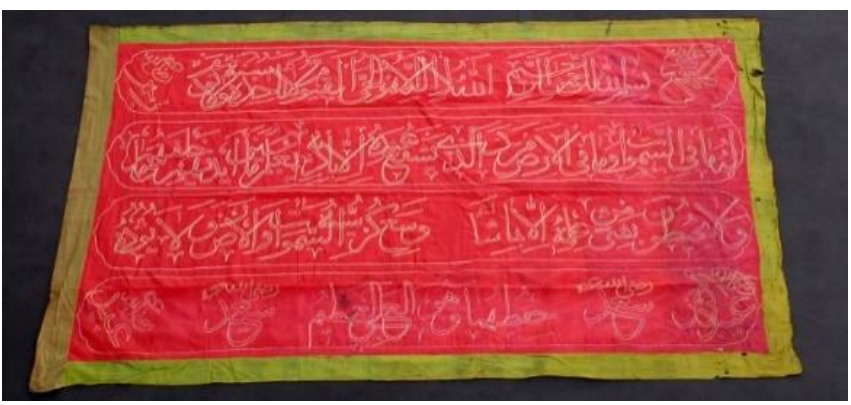

Resim 2: Kat. No. 2 (Ankara Etnografya Müzesi Arşivi)

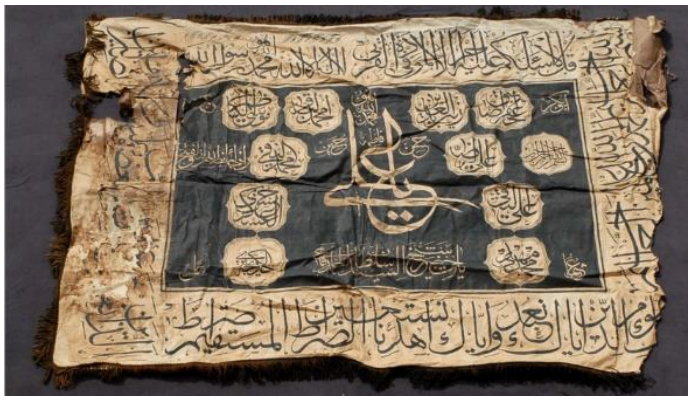

Resim 3: Kat. No. 3 (Ankara Etnografya Müzesi Arşivi)

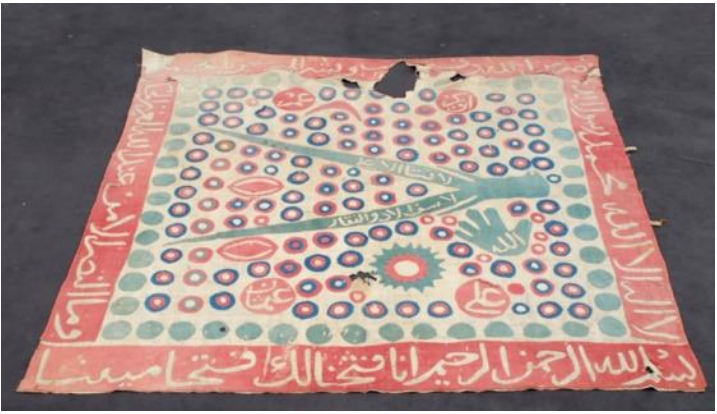

Resim 4: Kat. No. 4 (Ankara Etnografya Müzesi Arşivi) 


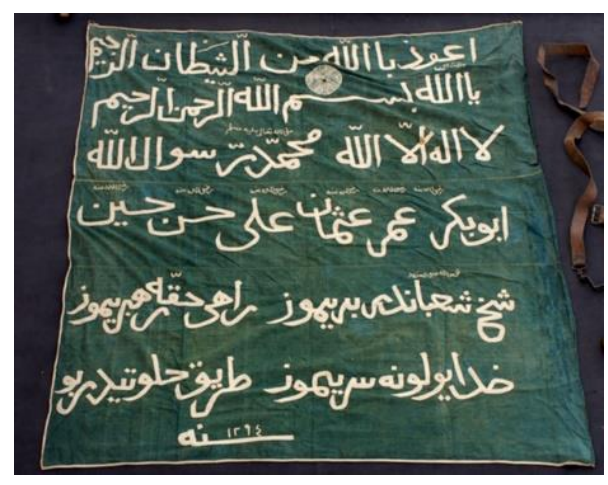

Resim 5: Kat. No. 5 (Ankara Etnografya Müzesi Arşivi)

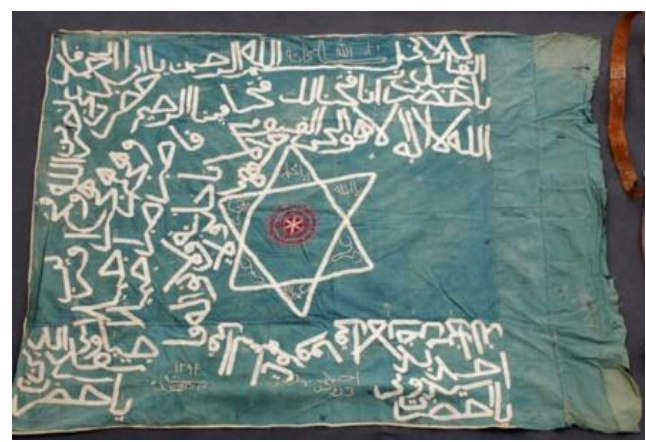

Resim 6: Kat. No. 6 (Ankara Etnografya Müzesi Arşivi)

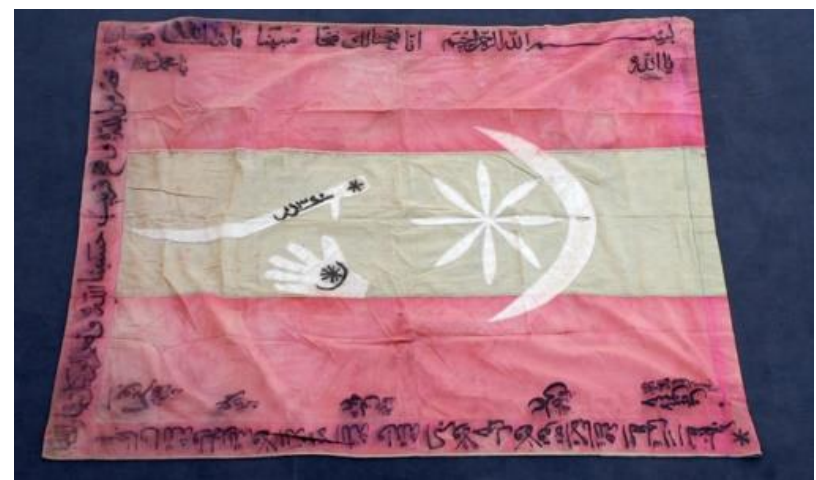

Resim 7: Kat. No. 7 (Ankara Etnografya Müzesi Arşivi)

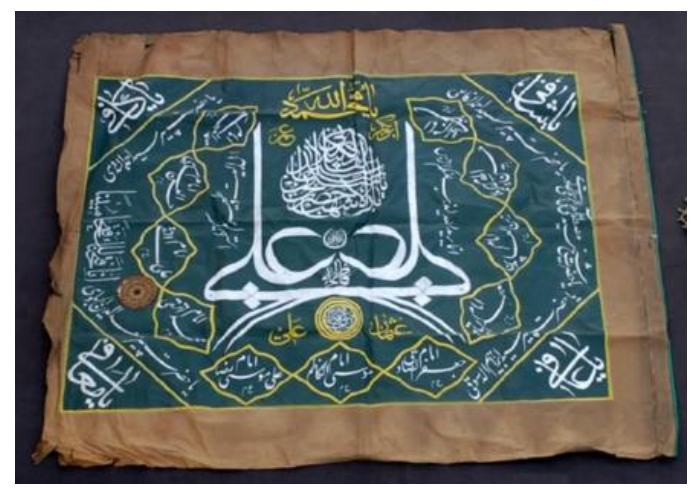

Resim 8: Kat. No. 8 (Ankara Etnografya Müzesi Arşivi) 


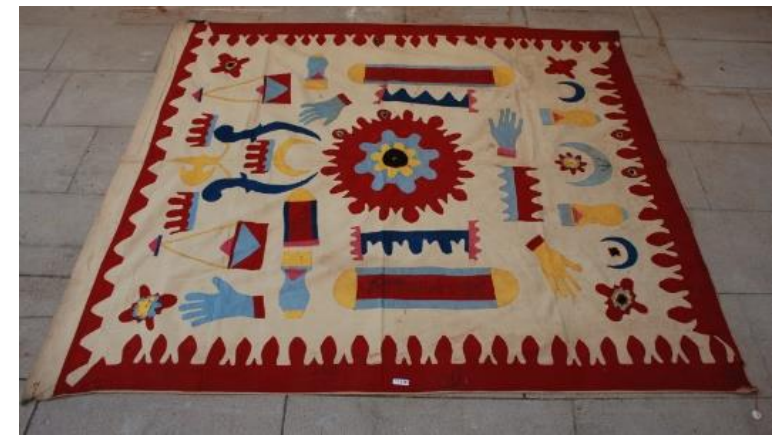

Resim 9: Kat. No. 9 (Ankara Etnografya Müzesi Arşivi)

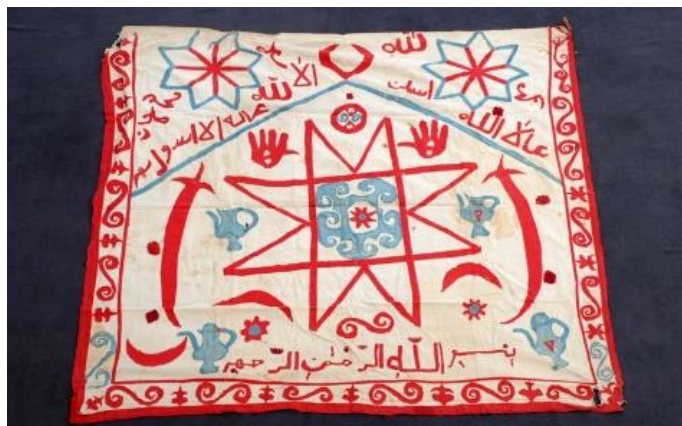

Resim 10: Kat. No. 10 (Ankara Etnografya Müzesi Arşivi)

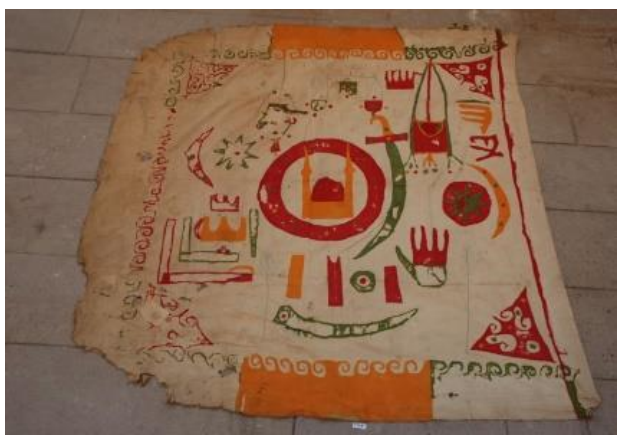

Resim 11: Kat. No. 11 (Ankara Etnografya Müzesi Arşivi)

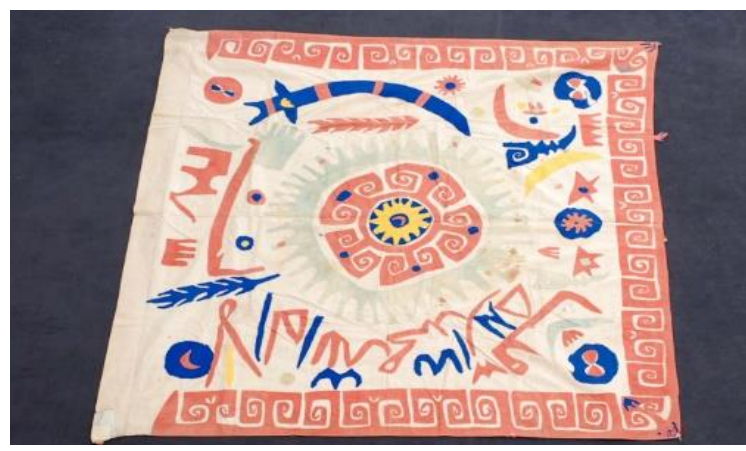

Resim 12: Kat. No. 12 (Ankara Etnografya Müzesi Arşivi) 


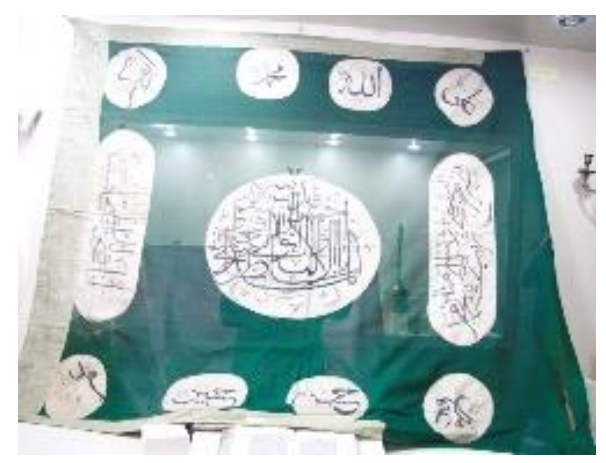

Resim 13: Kat. No. 13 (Yozgat Müzesi Arşivi)

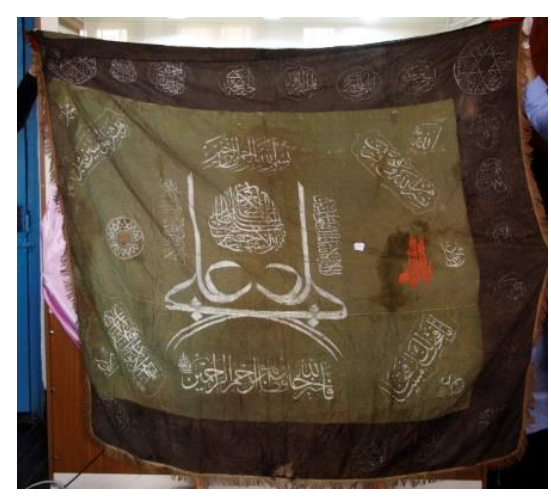

Resim 14: Kat. No. 14 (Yozgat Müzesi Arşivi)

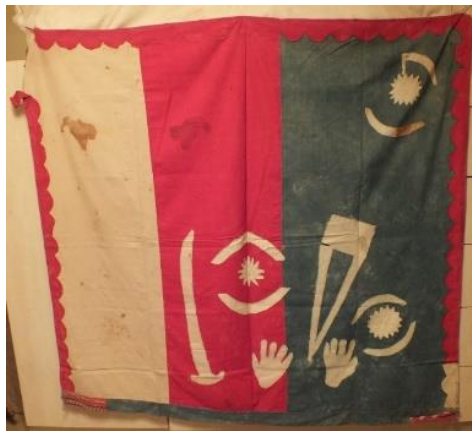

Resim 15: Kat. No. 15 (Ceylan, 2018)

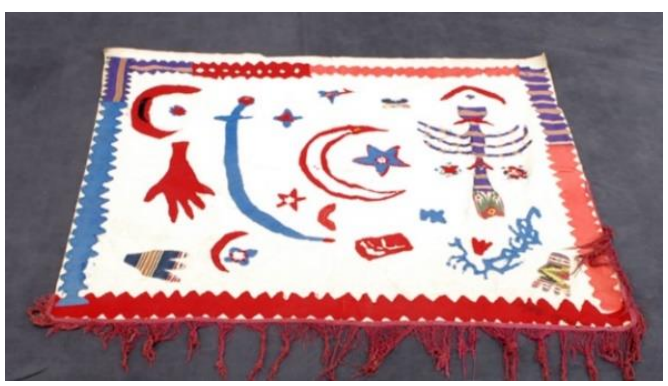

Resim 16: Kat. No. 16 (Ankara Etnografya Müzesi Arşivi) 


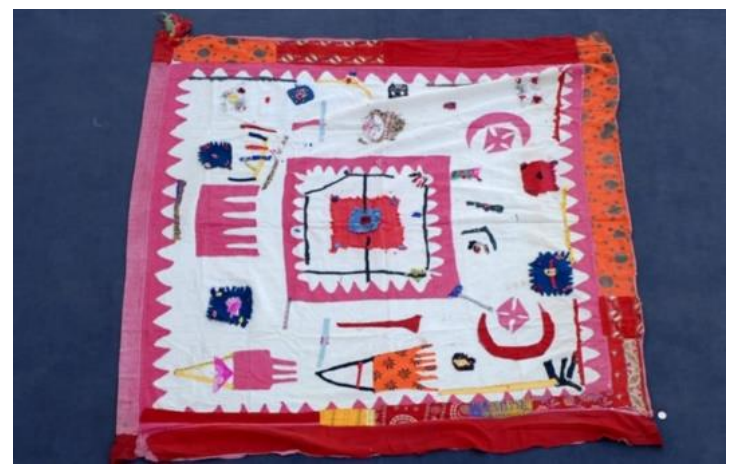

Resim 17: Kat. No. 17 (Ankara Etnografya Müzesi Arşivi)

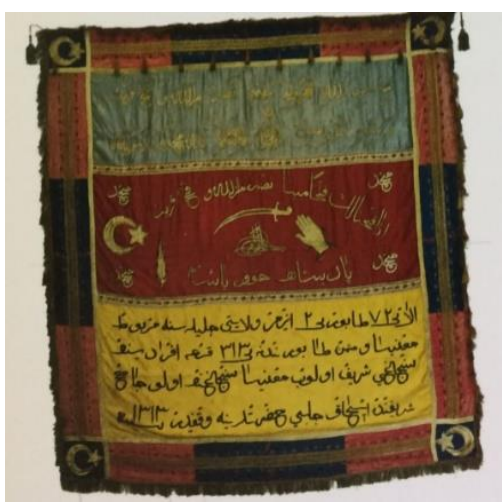

Resim 18: Konya Mevlâna Dergâhına Ait Sancak (Konya Mevlâna Müzesi Env. No. 3865, 19. Yüzyıl Naci Bakırc1, a.g.m, s. 247)

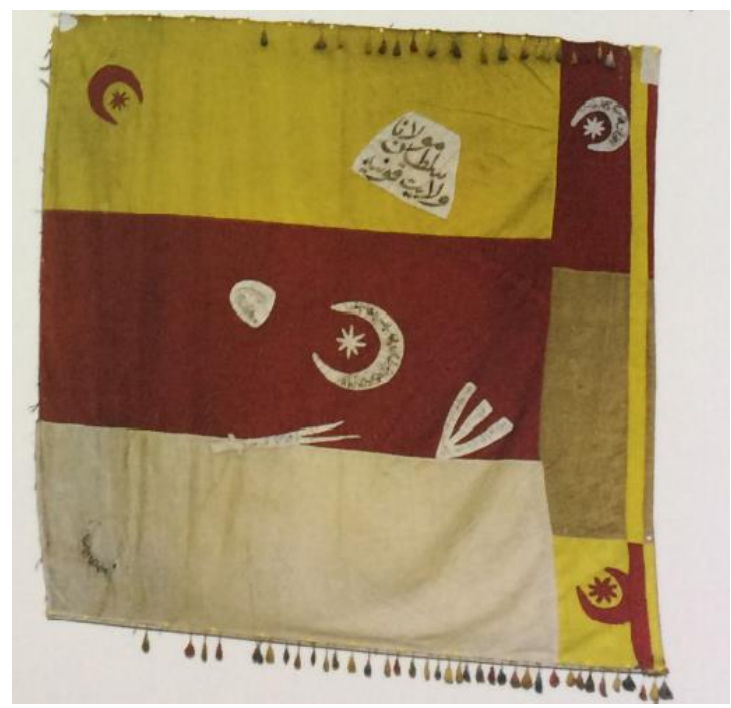

Resim 19: Konya Mevlevî Sancağı (Naci Bakırcı, a.g.m, s. 242) 